\title{
(In)visible Minorities and the Law in England
}

Les Minorités (in)visibles et le droit en Angleterre

\section{Gino G. Raymond}

\section{(2) OpenEdition}

Journals

Electronic version

URL: http://journals.openedition.org/rfcb/830

DOI: $10.4000 /$ rfcb.830

ISSN: 2429-4373

\section{Publisher}

CRECIB - Centre de recherche et d'études en civilisation britannique

\section{Electronic reference}

Gino G. Raymond, «(In)visible Minorities and the Law in England», Revue Française de Civilisation Britannique [Online], XXI-1 | 2016, Online since 20 July 2016, connection on 10 December 2020. URL : http://journals.openedition.org/rfcb/830 ; DOI : https://doi.org/10.4000/rfcb.830

This text was automatically generated on 10 December 2020.

\section{(c) (i) (9)}

Revue française de civilisation britannique est mis à disposition selon les termes de la licence Creative Commons Attribution - Pas d'Utilisation Commerciale - Pas de Modification 4.0 International. 


\title{
(In)visible Minorities and the Law in England
}

\author{
Les Minorités (in)visibles et le droit en Angleterre
}

Gino G. Raymond

\section{Introduction}

1 This article was occasioned by a number of major police investigations culminating in a series of high-profile prosecutions, involving groups of men, almost entirely from the Muslim Asian community. The way these prosecutions were portrayed, by the authorities and the media, shone a light on the broader issue of the way sensitivities are managed in the relationship between minorities and the law, and the paradoxes this engenders. The brackets around the first syllable of the first word in the title underscores an initial paradox: non-white minorities are manifestly visible in English society, yet as we shall see, in the official discourse of law enforcement officers and the authorities, in the context of the prosecutions mentioned above, there was a consistent attempt to occlude any significance that might be attached to ethnic or religious specificity. As the title also indicates, the focus of the article is England, given the independence of the Scottish legal system with regard to the rest of the United Kingdom and the different dynamics in community relations there.

\section{An ethos under scrutiny}

One of the assumptions embedded in the multicultural ethos in England is that if one is to succeed in building a cohesive national community out of a society characterised by evergrowing diversity, then it is vital to recognise ethnic and cultural specificity. There is one context, however, where that recognition has become problematized, due to the fear of stigmatising entire communities. One of the recurrent leading stories in the media since the beginning of the decade has been child sexual abuse, and in particular the grooming 
of teenage girls under the age of consent for sexual exploitation by gangs of men. A series of such rings was uncovered by the police, spreading down from the deprived cities of the north such as Bradford and Rotherham, down through Derby and Telford, and even reaching the affluent south in the city of Oxford. In May 2012, the highly mediatised guilty verdicts returned against 9 men for running a child sexual exploitation ring in Rochdale, highlighted the common thread linking the cases in the other town mentioned above: the rings were all led by, and almost entirely comprised of, Asian Muslim men. Mindful of the potential for this fact to be seized on and exploited by groups hostile to community cohesion, Greater Manchester police were at pains to elide any ethnic or cultural factors in terms of the motivation for this crime. There was, their spokesperson asserted: 'no racial element to the case [...] the main issue was older men exploiting vulnerable young girls'. ${ }^{1}$ The reaction of the Labour MP for Rochdale, Simon Danczuk, quoted in the same $\mathrm{BBC}$ report, was to retort that it would be 'daft not to believe that race plays a part' in the grooming. But the dangers of singling out individual communities had been amply demonstrated during the course of the previous year and may have been a factor influencing the discretion of the police and the prosecuting authorities.

3 After the discovery of a ring of Asian men in 2011 who had been grooming under-age girls for sex in Lancashire, the former Labour Home Secretary, Jack Straw, voiced his opinion to the media that some men of Pakistani origin saw white girls as 'easy meat'. The reaction was swift and came from within Straw's own party, implicitly at first, and then explicitly portraying Straw's remarks as the unfair stigmatisation of a minority community. Straw's fellow Labour MP, Keith Vaz, himself of Asian origin, rushed to the defence of the Pakistanis in his community and denied that the rings of abusers were symptomatic of a 'cultural' problem. While one of the Labour councillors for Burnley, Shah Hussain, condemned Straw unequivocally for homing in on men of Pakistani heritage and therefore 'victimising that community'. ${ }^{2}$ An unwritten and largely unspoken consensus seemed to have formed to the effect that if there were to be an attitudinal problem in certain minority communities, that was for those communities to address, and not for those from the wider host community. Furthermore, if such a dialogue were to be engaged, it would have to remain internal, and could not be shared with those outside of the communities affected. Those members who shared their concerns more broadly and more openly, ran the risk of being sanctioned by their own communities, according to the research of the women's rights campaigner Julie Bindel. In an interview with Mohammed Shafiq, the director of the Ramadhan Foundation, the latter confided that when he warned of the dangers of not confronting the sexual abuse of young girls by men in his community, some of its members sent him death threats. ${ }^{3}$

There was, however, one voice during the Labour years of government and opposition that expressed a consistent interest in the matter of the sexual exploitation of young girls, and that was Anne Cryer, the Labour MP for Ilkley in West Yorkshire, for almost 20 years. Partly because she was never bound by the constraints of ministerial office, and partly because members of her constituency were directly affected by this type of abuse, Mrs Cryer was a voice in the political wilderness, until the intense spotlight shone by the media on the issue made her an unavoidable point of reference. In January 2013 she appeared before the House of Commons Home Affairs Committee to answer questions as to why she thought child sexual grooming had gone on for so long without an effective remedy being applied by the agencies that should have been concerned. In her reply, Mrs Cryer pointed to the crucial lack of coordination between agencies such as the police, 
social services and health professionals, which allowed victims and perpetrators to slip through the net. But she also identified what she believed to be an underlying anxiety that held back the agencies in question because of the communities from which many of the perpetrators had emerged: the fear of being perceived as racist. And this fear, she argued, had grown in a major way after the Stephen Lawrence affair. ${ }^{4}$

Stephen Lawrence was a black teenager who was stabbed to death on 22 April 1993 in an unprovoked attack by a gang of white youths while he was waiting at a bus stop in Eltham, south-east London, with his friend Duwayne Brooks. Those suspected of the murder were identified in an anonymous letter to the police on April 24 and on May 7 a group of young men were arrested, of whom two were charged on June 23. On July 29, however, the police dropped the charges, claiming that the evidence given by Duwayne Brooks identifying the suspects was unreliable, prompting what would become the most high-profile and politicised campaign for justice in post-war British history. Dismayed by the inaction of the authorities, in 1994 the Lawrence family launched a private prosecution against the suspects released by the police, but this failed in 1996. On 14 February 1997, the deeply conservative Daily Mail newspaper threw its weight behind the Lawrence family's campaign for justice and carried on its front page the names of the five individuals it accused of Stephen's murder, and invited them to sue the newspaper. In the following month, at the behest of the Police Complaints Authority, the Kent Constabulary carried out an investigation into the widely-perceived mishandling of the Stephen Lawrence case by the Metropolitan Police. Finally, in July 1997, the Labour Home Secretary, Jack Straw, announced a public enquiry into the conduct of the Metropolitan Police investigation into Stephen's murder, to be chaired by the retired High Court Judge, William Macpherson, with the aim of drawing the lessons that the police needed to learn in dealing with racially-motivated crimes.

\section{From Scarman to Macpherson}

The Macpherson report appeared in 1999 and could be viewed as the culmination of a process that started with Lord Scarman, almost two decades earlier. While both emerged from very different circumstances, the issues of central concern in both reports related to a failure of policing in some sense or another. ${ }^{5}$ Simmering tension between the black community in Brixton, South London, and the police erupted in April 1981 after 'Operation Swamp' was implemented by the Metropolitan Police with the aim of cutting street crime in the area. The infamous 'Sus' law, which gave the police the freedom to stop and search anybody they suspected of planning to commit a crime, had long been felt by the black community to be a measure that was used to victimise them. During the course of six days in early April, the 'Sus' law was used to stop over 1000 people in Brixton. On April 10, rumours circulated of police brutality against a black man, and when this was followed by a police arrest, the frustration in sections of the community exploded into three days of rioting as predominantly young black men fought the police, attacked buildings and set fire to cars. By the time the inquiry into those events had reported, led by the Appeal Court judge, Lord Leslie Scarman, similar violence had erupted in other English towns, notably Liverpool and Manchester.

7 The Scarman report was ground-breaking in its time in that it was the first formal acknowledgement that there was racial prejudice in the Metropolitan Police, and that it had to be eliminated. As Scarman saw it: 'Racial prejudice does manifest itself 
occasionally in the behaviour of a few officers on the street [...]. The damage done by even the occasional display of racial prejudice is incalculable [...]. It is therefore essential that every possible step be taken to prevent and root out racially prejudiced attitudes in the police service'. ${ }^{6}$ But as the use of adjectives such as 'few' and 'occasional' suggest, Scarman would go on to maintain that racism was not systematic or part of the fabric of the police service. Subsequent events would prove Scarman's certainty to be misplaced. Riots would erupt in Brixton again, on 28 September 1985, after a police operation to arrest a man suspected of robbery went tragically wrong. The suspect was not at home but during the course of the dawn raid his mother, Cherry Groce, was accidently shot while still in bed by a firearms officer, and subsequently left crippled. So by the time Macpherson came to report his findings, and after years of media coverage regarding police failures in the investigation of Stephen Lawrence's murder, the identification of a systemic failure in the police's relationship with the black community was not unexpected.

The report's 70 key recommendations were robust and unequivocal. ${ }^{7}$ Number 11 aimed to make it impossible for racism to be passed off as the attitude of just a few rogue elements by not only making officers directly responsible for their failures in this regard, but their commanding officers indirectly responsible also:

The full force of race relations legislation should apply to all police officers, and chief officers of police should be made vicariously responsible for the acts and omissions of their officers relevant to that legislation.

Recommendation 30 was determined to make communities that were victims of raciallymotivated crime take centre-stage, and prevent members of those communities being ignored in the way Stephen Lawrence's family had been:

Police services and victim support services should ensure that their systems provide for the pro-active use of local contacts with minority ethnic communities.

Furthermore, in recommendation 48 the report underlined the principle of policing by consent, that good policing could not occur without good community relations and that in a culturally diverse society, the value of diversity had to be reflected in every aspect of police training:

There should be a consistent strategy to deliver appropriate training within all police services, based on the value of cultured diversity; training courses should be designed and delivered in order to develop the full understanding that good community relations are essential to good policing.

The long-standing grievance by the black community that, by the very nature of its operation, the Metropolitan Police was racist, was accepted by Macpherson and his commitment to combatting what would later be simply described as 'institutional' racism was reflected in one of the report's simplest, and arguably most radical recommendations. Recommendation 12 asserted: "A racist incident is any incident which is perceived to be racist by the victim or any other person."

12 The virtue of Macpherson's blanket definition of a 'racist' incident was that the police, and the authorities in general, would have no room for excuses if they failed to investigate a racially motivated crime, as they had so often failed to do in the past. The unintended consequence, according to Anne Cryer's testimony to the Home Affairs committee, was that it would prompt a general retreat by the police and other para-legal agencies vis-à-vis minority communities, even in situations that demanded an active engagement. There was an unwillingness to stretch a net that would catch victims, actual 
and prospective, and their abusers, for fear that individuals inside or outside those communities would interpret that action as racist. According to Macpherson, the mere perception of an action as racist simply made it so. In terms of everyday police practice, their effective sphere of operation appeared to have shrunk, ceding the space for greater autonomy to minority communities and in broader terms, appearing to concede the possibility of de facto parallel jurisdictions in English society.

\section{A space for parallel jurisdictions?}

Muslim academics and commentators like Tariq Ramadan noted the sense of anxiety in secular liberal democratic societies that hosted Muslim minorities, generated by the feeling that somehow they saw themselves as subject to a different legal code, and one that was not compatible with the progressive values of the host society. During the same period that stories of the sexual grooming of young girls by gangs of Muslim men became a recurrent feature of newspaper front pages, the media began to take a sustained interest in the growth of Sharia courts in the U.K. The Independent, for example, ran an article that attempted to address a number of key questions concerning the growth of Sharia courts, their operation and their standing vis-à-vis the English legal system. In an attempt at striking a balance in its investigation, the piece quoted Ramadan, who characterised the archetypal Western liberal reaction in the following way: 'In the West, the idea of Sharia calls up the darkest images of Islam [...] Many Muslim intellectuals do not dare even to refer to the concept for fear of frightening people or arousing suspicion of all their work by the mere mention of the word'. ${ }^{8}$ The 85 courts mentioned by The Independent, as Ramadan and others pointed out, did not refer to themselves as 'courts' but usually as 'councils', and much of their work was focused on providing information, much like Citizens' Advice Bureaux, but in their case to Muslim communities facing linguistic and other obstacles to their adaptation to their host community.

ther figures with a public platform, however, identified what they believed was the growing remit of Sharia councils with regard to family and divorce proceedings. The Conservative peer, Baroness Cox, attempted, unsuccessfully, to pilot a private members bill through Parliament aimed at regulating the work of Sharia councils in this field, and which had its first reading in the House of Lords on 7 June $2011 .{ }^{9}$ Her fear was that women who had been married only under Sharia law and therefore had no marriage document that would be recognized under English law, felt that their only hope of redress in the face of marital difficulties was to take their case to a Sharia council. For their part, according to Baroness Cox, many of those councils were misrepresenting themselves to the women in question as being able to pass legally binding decisions. Consequently, many women with a genuine grievance against their husbands felt obliged to accept the judgement of the councils even though they were often biased in favour of the husband.

The debate on Sharia law had gained considerable traction after a study, under the aegis of the think tank Civitas, had been widely trailed in the media and prompted widespread debate. In the study, the author, Denis MacEoin, staked out his position unequivocally and saw, in the rise of Sharia law, the prospect emerging of communities arrogating the right to live outside the law that applied to everybody else:

The introduction of sharia law into this country is a recipe for a dichotomous legal system that holds Muslims and non-Muslims to different standards. This is not a matter of eating halal meat or seeking God's blessing on one's marriage. It is a 
challenge to what we believe to be the rights and freedoms of the individual, to our concept of a legal system based on what parliament enacts, and to the right of us all to live in a society as free as possible from ethnic-religious division or communal claims to superiority and a special status that puts them in some respects above the law to which we are all bound. ${ }^{10}$

Nonetheless, the misgivings expressed by Baroness Cox and Denis MacEoin seemed to carry little weight with those tasked with overseeing the operation of the English legal system, especially the family division. To certain commentators, a landmark ruling was reached in the High Court in early 2013 that set a precedent allowing religious courts a legitimacy they had not enjoyed before vis-à-vis English courts. The ruling referred to the case of a Jewish couple living in London and facing a bitter marital breakdown. When the wife began to deprive the husband of access to his children, the husband initiated proceedings under the Hague Convention on child abduction. But before the case came to court in London, the couple decided to refer their dispute to a senior rabbi in the New York Beth Din and asked the English judge, Mr Justice Baker, if he would agree. Justice Baker examined the principles employed by the Beth Din and, finding them compatible with the laws of England and Wales, ultimately concurred with the key provisions of the arbitration conducted by the New York Beth Din and allowed them to inform the judgement finally released by the High Court in London. While Justice Baker made it clear in his ruling that the arbitration of the Beth Din alone could not be binding, as it could not supplant the jurisdiction of the High Court, for some observers it marked a major departure from English legal practice: it was the first time a family court had effectively delegated some of its authority to a religious court for arbitration. For a spokesman for the Muslim Council of Britain, the outcome for the Jewish couple opened the door to a change that could have profound repercussions for Muslim couples also: 'If it leads to the eventual acceptance of Sharia court divorces, then Muslims will be very encouraged'. ${ }^{11}$

\section{Self-legislating communities?}

The sub-text that was developing in the pages of the conservative Daily Telegraph was that the law was increasingly turning a blind eye to the way certain minority communities operated according to their own customs and beliefs, even if those customs and beliefs were at variance with the laws of their host society. During the weeks preceding the judgement pronounced by Justice Baker, the Telegraph covered an incident and the ensuing consequences that appeared to justify the narrative it was developing. During the festive period leading up to early January 2013, Muslim vigilante groups appeared on the streets of Tower Hamlets, Whitechapel and Shoreditch, boroughs with large concentrations of members from the Asian Muslim community. The vigilante groups took as their mission the task of curbing the consumption of alcohol on the streets and advising women on how to dress modestly. Footage posted on You Tube purportedly showed a group calling itself Muslim Patrol verbally abusing non-Muslim revellers who had strayed too close to the front of a mosque and telling them that they had no right to be there. ${ }^{12}$ While it was impossible to verify the source of the footage, notably whether it was genuinely the work of Muslim vigilantes or white racist provocateurs, the story gained currency and the communities and parties concerned felt obliged to react. Outrage in some quarters at what was alleged to be the homophobic actions of the vigilantes forced the Metropolitan Police to respond, but the London police followed in the footsteps of the Greater Manchester Police over the sexual grooming scandal, and 
refused to situate the alleged abuses in any kind of cultural context. Homophobia was homophobia and would be prosecuted like any other act that fell in the category of 'hate crime', irrespective of its provenance. It was incumbent on the local community itself to determine whether the cultural conditioning within its ranks was in any way responsible or culpable. Shaikh Shams, imam of the East London Mosque, situated in one of the boroughs where the vigilantes were alleged to have been operating, felt an obligation to point his finger at what he considered a fundamental misunderstanding of Islam among some members of his community:

When things like this happen Muslims tend to privately voice their opposition. But nobody wants to address this perspective from an Islamic or Sharia point of view to simply articulate that this is actually wrong Islamically. [...] Islam was celebrated for allowing non-Muslim people who lived in an Islamic state to live according to their principles, their religion, their Sharia. This is in Muslim lands in the time of the Caliphate. And we see this video where, in the streets of Tower Hamlets, in the streets of England. Enough said, right? ${ }^{13}$

18 The intervention in the debate on how to deal with the conflict between community and national values, coming from a leader of the Muslim community in East London, was perceived as a positive one. But it did nonetheless raise fundamental questions. The first one was whether the condemnation of the alleged actions of the vigilantes as 'wrong islamically' was an adequate one. It appeared to remain a community-based and selfreferential criterion that did not accommodate the legal principles and the values they represented of wider English society. Secondly, the question arose as to whether the defence against possible sectarian violence should depend on the intervention of a religious leader from the community concerned. The lessons of Brixton and subsequent confrontations between the police and minority communities in England's urban centres had led the police to develop a justifiably pragmatic, piece-meal and community-based approach to their task. Notwithstanding the obvious benefits of policing by cooperation and consent, the nagging doubt about Macpherson expressed by Anne Cryer MP continued to grow. Had Macpherson's catch-all definition of racism unintentionally led to a situation where the fear of being perceived as discriminating against black and minority ethnic communities by law enforcement agencies, left some of the most vulnerable members of society beyond the protection of the law? Moreover, had this wellintentioned reluctance to intervene in communities with a strong and separate sense of identity inadvertently encouraged some members of those communities to believe that they possessed some kind of exemption from the laws governing everybody else?

In a surprisingly candid interview to The Times, Her Majesty's Chief Inspector of Constabulary for England and Wales reflected on those communities who he believed had developed a presumption that the law and its enforcement was something for them to decide:

There are some communities born under other skies who will not involve the police at all [...]. There are cities in the Midlands where the police never go because they are never called. They never hear of any trouble because the community deals with that on its own [...]. They just have their own form of community justice [...] it could be anything from low-level crime to murder [...] honour killings are the most extreme example. ${ }^{14}$

20 Winsor's comments were in the context of a wide-ranging report commissioned by the Home Secretary, Theresa May, into the effectiveness of policing in England and Wales. The most hostile reactions to his comments came, in fact, from the police, who refuted what they saw as an accusation of passivity when faced with the challenge of 
investigating possible crimes in tight-knit ethnic communities. Another underlying implication that was not overlooked, however, was that community-based notions of what was legally acceptable had led to significant numbers of invisible victims of acts perpetrated by individuals who had become less visible in the eyes of law enforcement agencies. While newspapers like The Telegraph pursued their traditional focus on public order, during the course of 2013 The Guardian had begun to investigate the fate of minorities within minorities, and to explore the imperative of intervention in community affairs when faced with an issue as difficult and compelling as female genital mutilation (FGM).

\section{FGM: community autonomy and legal intervention}

21 The investigative approach taken by The Guardian was to respond to the voices of women from within the communities affected by FGM, and to give them the opportunity to express themselves, which was being denied to them, sometimes violently, within their own communities. As Efua Dorkenoo, a director of the Equality Now group campaigning against FGM explained:

Any woman or girl who speaks out against FGM is in very serious danger from extended members of their family, their neighbours and from their community, especially from so-called gatekeepers of their community who control and harass them if they raise their voices [...] You can't speak out against it without risking your life. ${ }^{15}$

Other voices and groups, speaking notably for British-Somali young women, such as the Daughters of Eve and Integrate Bristol, were given a platform, and the fact that these were voices from within the communities criticising community practices and attitudes circumvented anxieties that the exposure given to the issue of FGM might be tainted by liberal condescension vis-à-vis minority communities.

FGM had been made a criminal act in England and Wales in 1985, but it took almost two decades for the government to realise that the provisions of the legislation banning it were not sufficiently robust. In 2003 therefore the existing legislation was superseded by the Female Genital Mutilation Act, which closed an important loophole allowed by the 1985 Act. Under the new Act, it would no longer be possible to take a female settled in Britain to a foreign destination for FGM to be performed. This change, plus harder sanctions against anyone aiding and abetting in the act of FGM, still did not, however, result in any prosecutions. As Keir Starmer, an erstwhile head of the Crown Prosecution Service admitted to the BBC in 2013, the authorities had been too passive:

I think we stood back and we waited for a victim to walk through the door of a police station. That was never going to happen [...] We need a proactive strategy [...] because young girls are very unlikely to come forward with evidence against their own family and risk going into care. ${ }^{16}$

In the view of many health and social care professionals who had to deal with the consequences of FGM, the law had to be brought centre stage in society if it was to succeed in protecting girls and young women from this practise. ${ }^{17}$ If, for obvious reasons, victims could not or would not testify against their families or communities with regard to the crime of FGM, the authorities could adopt precedents already established in the prosecution of other crimes. Victims can, for example, be allowed not to give evidence or 
participate directly in trials for crimes against pre-verbal children, people with dementia, learning difficulties, in certain cases of domestic violence and also sexual abuse.

In contrast to the professionals discreetly pressing for a more proactive legal response to the challenge posed by FGM, the media, and especially The Guardian, found a remarkable standard bearer in its campaign against FGM. Fahma Mohamed, a secondary school student in Bristol, rose to local notoriety as a leading figure in the charity, Integrate Bristol, which campaigns for more education about FGM in schools. By mid-February 2014 she had shot to national prominence as a figurehead for the 'End FGM' campaign backed by The Guardian, which promoted a petition on a campaigning website that attracted over 100,000 signatures in the space of 24 hours. The broader media coverage given to Fahma Mohamed, on television and in the press, catapulted her into the category of global celebrity and secured the backing of the United Nations general secretary, Ban Ki-Moon, for her campaign, as well as that of the Pakistani schoolgirl Malala Yousafzai, who had won world-wide admiration for her stand against the Taliban and in favour of education for girls. The pressure on the Education Minister, Michael Gove, to promote awareness in schools of the battle against FGM was proving irresistible. ${ }^{18}$ The visibility given to the anti-FGM campaign by Fahma Mohamed leading a delegation to the Department of Education in Whitehall in order to deliver the Guardian-backed petition, underscored what was perceived by many as the timidity of the legal establishment regarding prosecutions for the crime of FGM. Within weeks the Crown Prosecution Service announced the first ever case to be brought to trail, but there was to be an unexpected twist in this prosecution. The accused were a consultant obstetrician, Dr Dhanuson Dharmasena, and the colleague who had assisted him in delivering care to a mother giving birth, and who had already been a victim of FGM. The dismay in the medical profession that the terms of the 2003 anti-FGM legislation were being interpreted in such a way led to a mobilisation of Dr Dharmesena's colleagues. In an open letter published in The Guardian, Dr Dharmasena's colleagues underlined their conviction that the government and legal authorities were still refusing to look in the direction of the communities and cultures where FGM was really happening:

There is a world of difference between FGM and repairing cuts that are necessary to allow a baby's delivery. Prosecuting professionals for so-called FGM under these circumstances distracts us from the real issues - namely, ensuring that girls are not sent abroad for FGM, that such operations are not performed in the UK, and that we help people in countries where this is endemic to change cultural attitudes. ${ }^{19}$

The indictment by the doctors of the timidity of the government and its law officers regarding the effective prosecution of FGM was powerfully vindicated by the report of the parliamentary Home Affairs Committee in July 2014, which contained a blanket condemnation of the authorities and the caring professions for failing the victims of FGM, actual and potential. ${ }^{20}$ The cost in human suffering was summed up in the following terms in paragraph 19 of the report:

The failure to respond adequately to the growing prevalence of FGM over recent years has likely resulted in the preventable mutilation of thousands of girls to whom the state owed a duty of care. This is a national scandal for which successive governments, politicians, the police, health, education and social care sectors all share responsibility.

Paragraph 47 identified the hindrance posed by well-intentioned but ultimately misguided concerns about cultural sensitivities that led to FGM not being prosecuted with as much vigour as other forms of child abuse: 
Misplaced concern for cultural sensitivities over the rights of the child is one of the main reasons why the UK has failed to tackle FGM to date. A key objective for a national action plan on FGM must be to overcome practitioners' own reluctance to address FGM so that they respond to it in the same way as other forms of child abuse.

Interestingly, for the purposes of this article, paragraph 28 contained distinct echoes of the Home Affairs Committee report on the sexual grooming of children that had appeared a few years earlier. More specifically, the anxiety expressed by Anne Cryer that after the Macpherson report and its catch-all definition of racism, too many professionals are afraid of intervening: "Even when they are aware, professionals may be reluctant to intervene because of cultural sensitivity and a fear of being seen as racist [...]."

\section{Conclusion}

Using the media as a means of tracking the perception of social issues is not without potential risks. A notable one is the fact that the way the media engages with social issues is often configured through the depiction of crisis, actual or imminent. ${ }^{21}$ Headlines, written or spoken, are more attention-grabbing when they evoke community failures or shortcomings in governance. After the headlines generated by the actions of Fahma Mohamed and the report of the parliamentary Home Affairs Committee on FGM, the media rapidly switched its attention to the apparent crisis gripping the moral character of the governing elite in Britain, with stories that started to swirl concerning a deceased Liberal MP, Cyril Smith, who was alleged to have been allowed to indulge his passion for young boys through the willingness of parliamentary friends and colleagues to turn a blind eye. Nonetheless, the responses from different sections of the media to the issues surrounding minorities and the law have assumed a complexity that translates the influence of diversity over recent decades and provide spaces in which identities can be challenged and changed. ${ }^{22}$ The reactive nature of local and central government, the responses of law enforcement agencies, and the way these have been depicted in the media, convey a long and ongoing process of evolution which reflects what might be called the 're-coding of race' in English society. ${ }^{23}$ As this article endeavours to illustrate, the consequences for the British conception of citizenship are numerous and challenging.

Biographie : Gino G. Raymond est Professeur de French studies au département de français de l'Université de Bristol. Ses travaux, souvent comparatistes, portent sur la société française contemporaine, notamment sur la $\mathrm{V}^{\circ}$ République. Parmi ses publications les plus marquantes, on notera The French Communist Party During the Fifth Republic (Palgrave Macmillan, 2005); The Construction of Minority Indentities in France and Britain (Palgrave Macmillan, 2007, co-editeur avec Tariq Modood) ou encore The Sarkozy Presidency: Breaking the Mould? (Palgrave Macmillan, 2013, éditeur). Il est par ailleurs un des principaux traducteurs de Pierre Bourdieu en langue anglaise. 


\section{BIBLIOGRAPHY}

Baroness Cox, Sponsor, Private Members' Bill, Arbitration and Mediation Services (Equality) Bill [HL] 2010-12. [http://services.parliament.uk/bills/2010-11/arbitrationandmed]

Bindel, J., An Unpunished Crime: The Lack of Prosecutions for Female Genital Mutilation in the UK (London, New Culture Forum, 2014).

Bindel, J, ‘Gangs, girls and grooming, Standpoint Magazine, December 2010.

[http://standpointmag.co.uk/print/3576]

Bowling, B., Violent Racism: Victimisation, Policing and Social Context (Oxford, OUP, 1998).

"Consultant obstetricians and gynaecologists, in defence of Dr Dhanuson Dharmasena, 'FGM charge obscures the real issues"', The Guardian, 27/03/14.

Cottle S. (ed.), Ethnic Minorities and the Media (Buckingham, Open University Press, 2000).

Cryer, Anne MP, Uncorrected Transcript of Oral Evidence, HC-182-xi, House of Commons, Oral Evidence Taken Before the Home Affairs Committee on Localised Child Grooming, Tuesday 29 January 2013, Evidence Heard in Public Questions 799-816. [http:// www.publications.parliament.uk/pa/cm201213/.../uc182-xi/uc18201.pdf].

Franklin, B. (ed.), Social Policy, the Media and Misrepresentation (London, Routledge, 1999).

Hill, A., "Female genital mutilation campaigners face death threats and intimidation", The Guardian, 8 May 2013. [http://www.theguardian.com/society/2013/may/08/female-genitalmutilation-death-intimidation]

Home Affairs Committee, Female Genital Mutilation: The Case for a National Action Plan, HC201 (London, The Stationery Office Limited, 2014).

Lord Scarman, The Scarman Report. The Brixton Disorders 10-12 April 1981 (London, Penguin, 1982).

Maceoin, D., Sharia Law or “One Law for All”? (London, Civitas, 2009).

Macpherson, William, The Stephen Lawrence Inquiry (London, HMSO, 1999).

McLaughlin, E. \& Murji, K. “After the Stephen Lawrence Report”, Critical Social Policy 19: 3 (2000).

Parveen, N, “Jack Straw sex grooming comments: the reaction", Lancashire Telegraph, 10 January 2011.

"Muslims condemn behaviour of Islamic vigilantes", The Daily Telegraph. [http:// www.telegraph.co.uk/news/uknews/crime/9831115/Muslims-condemn-behaviour-of-Islamicvigilantes.html]

“'Muslim Patrol' Sharia vigilantes take to streets in East London - Truthloader. [http:// www.youtube.com/watch?v=nw2w7ACogaY]

“Gangs, girls and grooming”, Standpoint Magazine, December 2010.[http://standpointmag.co.uk/ print/3576]

"Rochdale Abuse: Social services missed opportunities" (BBC News Manchester, 27 September 2012). 
[http:www.bbc.co.uk/news/uk-england-manchester-19739073]

Smith, A. "The Big Question: How do Britain's Sharia courts work, and are they a good thing?" ( The Independent, 30 June 2009). [http://www.independent.co.uk/news/uk/home-news/the-bigquestion-how-do-britains-sharia-courts-work-and-are-they-a-good-thing-1724486.html]

Topping, A., "FGM campaigner Fahma Mohamed urges Gove to help end cycle of abuse", (The Guardian, 25 February 2014). [http://www.theguardian.com/society/2014/feb/25/fgm-fahmamohamed-michael-gove-schools-female-genital-mutilation]

Winsor, T., interview (The Times, 17 January 2014).

\section{NOTES}

1. "Rochdale Abuse: Social services missed opportunities" (BBC News Manchester, 27 September 2012).

[http:www.bbc.co.uk/news/uk-england-manchester-19739073] (Accessed 17 March 2016).

2. N. Parveen, "Jack Straw sex grooming comments: the reaction", (Lancashire Telegraph, 10 January 2011).

3. J. Bindel, "Gangs, girls and grooming”, (Standpoint Magazine, December 2010). [http://standpointmag.co.uk/print/3576] (Accessed 14 February 2016).

4. Anne Cryer MP, Uncorrected Transcript of Oral Evidence, HC-182-xi, House of Commons, Oral Evidence Taken Before the Home Affairs Committee on Localised Child Grooming, Tuesday 29 January 2013, Evidence Heard in Public Questions 799-816. [http:// www.publications.parliament.uk/pa/cm201213/.../uc182-xi/uc18201.pdf] (Accessed 14 February 2016).

5. B. Bowling, Violent Racism: Victimisation, Policing and Social Context (Oxford, OUP, 1998), p. xiv.

6. Lord Scarman, The Scarman Report. The Brixton Disorders 10-12 April 1981 (London, Penguin, 1982), pp. 105-106.

7. William Macpherson, The Stephen Lawrence Inquiry (London, HMSO, 1999).

8. In A. Smith, “The Big Question: How do Britain's Sharia courts work, and are they a good thing?", The Independent, 30 June 2009. [http://independent.co.uk/news/uk/home-news/the-bigquestion-how-do-britains-...] (Accessed 14 February 2016).

9. Baroness Cox, Sponsor, Private Members' Bill, Arbitration and Mediation Services (Equality) Bill [HL] 2010-12. [http://services.parliament.uk/bills/2010-11/arbitrationandmed] (Accessed 14 February 2016).

10. D. Maceoin, Sharia Law or "One Law for All"? (London, Civitas, 2009), p. 73.

11. R. Alleyne, "Sharia divorces could be allowed after legal ruling" (The Daily Telegraph, 1 February 2013). [http://www.telegraph.co.uk/news/uknews/9841370/Sharia-divorces-could-beallowed-...] (Accessed 14 February 2016).

12. "Muslim Patrol Sharia vigilantes take to streets in East London", Truthloader [http://www.youtube.com/watch?v=nw2w7ACogaY] (Accessed 14 February 2016).

13. The Daily Telegraph, "Muslims condemn behaviour of Islamic vigilantes" [http:// www.telegraph.co.uk/news/uknews/crime/9831115/Muslims-condemn-behaviour-of-Islamicvigilantes.html] (Accessed 14 February 2016).

14. T. Winsor, interview (The Times, 17 January 2014).

15. In A. Hill, "Female genital mutilation campaigners face death threats and intimidation" (The Guardian, 8 May 2013).

[http://www.theguardian.com/society/2013/may/08/female-genital-mutilation-deathintimidation] (Accessed 21 April 2014). 
16. In J. Bindel, An Unpunished Crime: The Lack of Prosecutions for Female Genital Mutilation in the UK (London, New Culture Forum, 2014), p.22.

17. Ibid., p.23.

18. A. Topping, "FGM campaigner Fahma Mohamed urges Gove to help end cycle of abuse" (The Guardian, 25 February 2014).

[http://www.theguardian.com/society/2014/feb/25/fgm-fahma-mohamed-michael-goveschools-female-genital-mutilation] (Accessed 14 February 2016).

19. Consultant obstetricians and gynaecologists, in defence of Dr Dhanuson Dharmasena, "FGM charge obscures the real issues" (The Guardian, 27 March 2014).

20. Home Affairs Committee, Female Genital Mutilation: The Case for a National Action Plan, HC201 (London, The Stationery Office Limited, 2014).

21. B. Franklin (ed.), Social Policy, the Media and Misrepresentation (London, Routledge, 1999), p. 2.

22. S. Cottle (ed.), Ethnic Minorities and the Media (Buckingham, Open University Press, 2000), p.2.

23. E. McLaughlin \& K. Murji, "After the Stephen Lawrence Report", Critical Social Policy, 19: 3, (2000), pp.371-385, p. 377.

\section{ABSTRACTS}

This article evokes the contradictions of the English judicial system and the political class with regard to the rights of citizens from minority communities, notably Muslim ones. Whether it is violence aimed at women, the interpretation of marriage rights or the defence of a sectarian notion of community, English courts are sometimes inclined to tolerate citizens behaving in a way that is characterised by particularism and inequality. The report by Lord Scarman after the Brixton riots, followed by Lord Macpherson's on the death of the teenager Stephen Lawrence, would appear to have opened the door to an interpretation of racism which hinders the willingness of the authorities to intervene in certain communities, and which might be seen to challenge the principle of equality underlying the concept of citizenship.

Cet article évoque les contradictions du système judiciaire anglais et de la classe politique concernant les droits des citoyens issus des communautés minoritaires, notamment musulmanes. Qu'il s'agisse des violences faites aux femmes, l'interprétation des droits matrimoniaux ou la défense d'un communautarisme sectaire, les tribunaux anglais se montrent parfois disposés à tolérer un comportement citoyen caractérisé par le particularisme et l'inégalité. Le rapport de Lord Scarman après les émeutes de Brixton, suivi par celui de Lord Macpherson sur la mort de l'adolescent Stephen Lawrence, auraient ouvert la porte à une interprétation du racisme qui freine la volonté d'intervenir au sein de certaines minorités de la part des autorités, et constitueraient un défi au principe égalitaire qui sous-tend la conception de la citoyenneté.

\section{INDEX}

Mots-clés: abus sexuels sur mineurs, racism, Rapport Scarman, Rapport Macpherson

Keywords: child sexual grooming, racism, Scarman Report, Macpherson Report 
AUTHOR

GINO G. RAYMOND

University of Bristol 